\title{
EFFECT OF VARIOUS NUCLEOTIDES AND DRUGS ON MICROSOMAL THIAMINE DIPHOSPHATASE ACTIVITY IN RAT BRAIN
}

\author{
Heitaroh Iwata, Toshio Matsuda, and Akemichi BabA ${ }^{1}$ \\ Department of Pharmacology, Faculty of Pharmaceutical Sciences, \\ Osaka University, Suita, Osaka, Japan
}

(Received May 22, 1975)

\begin{abstract}
Summary The basic properties of microsomal thiamine diphosphatase (TDPase) in rat brain were examined. It was mainly localized in the microsomal fraction. Microsomal TDPase showed an absolute requirement for divalent cation which was best satisfied by $\mathrm{Ca}^{++}$. Theophylline $(1 \mathrm{~mm})$, NADP $(0.1 \mathrm{~mm})$ and NADPH $(0.1 \mathrm{~mm})$ significantly inhibited its activity. However, caffeine, theobromine, NAD and various putative neurotransmitters did not affect the enzyme activity. UDP was inhibitory and IDP was a competitive inhibitor, but ATP had no effect on the enzyme activity.
\end{abstract}

In investigations on the relation of thiamine with neuronal function at an enzymic level, earlier studies from this laboratory (1-4) and others (5-9) clarified some properties of the enzymes degrading phosphorylated thiamine in the central nervous system. More recently, we $(10,11)$ found that chlorpromazine inhibited brain TTPase and activated TDPase in vitro and we suggested that these enzyme activities might be associated with the micro-environment in the membrane. These findings indicate a possible significance of these enzymes in the nerve membrane.

However, the nature of brain TDPase has not been elucidated so fully as that of the liver enzyme (12). For instance, reports on the effect of ATP on the brain enzyme are conflicting $(1,7,8)$ and it is not clear whether this enzyme is identical with a general nucleoside diphosphatase in the brain. In this paper, we studied the effects of various drugs and nucleotides on the activity of microsomal TDPase from rat brain.

\section{EXPERIMENTAL}

1. Thiamine diphosphate. TDP was obtained from Sigma Chemical Co., St. Louis. It was found to be $97 \%$ pure by paper electrophoresis (4).

1 岩田平太郎, 松田敏夫, 馬場明道 
2. Subcellular fractionation. Adult male Sprague-Dawley rats weighing 200-250 g were sacrificed by decapitation and the brain was rapidly removed and homogenized in 10 volumes of ice-cold $0.25 \mathrm{M}$ sucrose using a glass homogenizer fitted with a Teflon pestle. Subcellular fractionation was carried out as described previously (4). The resulting pellets were suspended in $0.25 \mathrm{M}$ sucrose for enzyme assay. Before use in experiments on the effects of divalent cations, the microsomal fraction was dialysed against deionized distilled water for $18 \mathrm{hr}$.

3. Enzyme assay. Unless otherwise indicated, the standard reaction mixture contained $75 \mathrm{~mm}$ Tris- $\mathrm{HCl}(\mathrm{pH} 9.0), 4 \mathrm{mM} \mathrm{CaCl}_{2}, 4 \mathrm{~mm}$ TDP and about 200$800 \mu \mathrm{g}$ of protein in a final volume of $2.7 \mathrm{ml}$. After $5 \mathrm{~min}$ of preincubation, the reaction was started by addition of TDP and carried out for $30 \mathrm{~min}$ at $37^{\circ} \mathrm{C}$. The reaction was terminated by addition of cold perchloric acid to a final concentration of $6 \%$. Aliquots of deproteinized supernatant were then assayed for inorganic phosphate by the method of BAGINSKI et al. (13) or for thiamine monophosphate (TMP) by paper electrophoresis, as described previously (4).

Protein was determined by the procedure of Lowry et al. (14).

4. Acetone treatment. In order to increase the activity of TDPase and to decrease that of ATPase, the enzyme preparations were treated with acetone as described previously (3). This treatment of microsomes resulted in an increase of the specific activity of TDPase to about 4-fold and a decrease of that of ATPase to about one-third of the original activities, respectively.

\section{RESULTS}

\section{Subcellular distribution}

Subcellular fractionation of the brain (Table 1) revealed that the mitochondrial and microsomal fractions contained high percentages (39\% and $32 \%$, respectively) of the total activity. The microsomal fraction had the highest specific activity. The activity in the supernatant fraction was negligible.

The microsomal fraction has several phosphatase activities such as nucleoside di- and triphosphatases. Actually, the hydrolysis activity of ATP was much higher than that of TDP in this fraction, even though the former was measured at optimal condition for the latter. However, as is evident from data in Table 2, the amount of TMP detected in the reaction mixture increased linearly with time, in quantitative agreement with the rate of hydrolysis, measured as release of inorganic phosphate. Paper electrophoresis of the reaction products revealed that only TMP was produced with no appearance of either TTP or free thiamine.

\section{Effects of divalent cations}

Microsomal TDPase activity exhibited an absolute requirement for cation, which was satisfied by $4 \mathrm{~mm} \mathrm{Ca}^{++}, \mathrm{Mg}^{++}$or $\mathrm{Mn}^{++}$, but not by $4 \mathrm{~mm} \mathrm{Co}^{++}$or $\mathrm{Zn}^{++}$ (Fig. 1). Among the divalent cations tested $\mathrm{Ca}^{++}$was the most effective and its 
Table 1. Subcellular distribution of TDPase activity in rat brain.

\begin{tabular}{lcc}
\hline \multicolumn{1}{c}{ Fraction } & $\begin{array}{c}\text { Activity } \\
\mu \text { moles } \mathrm{P}_{\mathrm{i}} / \mathrm{mg} \text { protein } / \mathrm{hr}\end{array}$ & $\%$ of total activity \\
\hline Homogenate & $0.37 \pm 0.01$ & $-\mathrm{a}$ \\
Nuclei & $0.39 \pm 0.03$ & $23.2 \pm 0.4$ \\
Mitochondria & $0.35 \pm 0.03$ & $38.8 \pm 0.9$ \\
Microsomes & $0.87 \pm 0.03$ & $31.6 \pm 0.9$ \\
Supernatant & $0.10 \pm 0.01$ & $6.4 \pm 0.9$ \\
\hline
\end{tabular}

a About $92 \%$ of the total activity of the homogenate was recovered in all the subcellular fractions. Each value is the mean $\pm \mathrm{S}$. E. of values in four separate experiments. Procedures used for subcellular fractionation and assay are described in EXPERIMENTAL.

Table 2. Stoichiometry of the TDPase reaction in brain microsomes.

Incubation condition is described in EXPERIMENTAL. Reaction was terminated by the addition of ice-cold $\mathrm{HCl}$ (final concentration, $0.07 \mathrm{~N}$ ). After centrifugation one portion of the supernatant was used for the assay of Pi and another was diluted with $50 \mathrm{~mm}$ acetate buffer ( $\mathrm{pH}$ 3.8) and used for the electrophoretic and fluorometric determination of the reaction mixture.

\begin{tabular}{ccc}
\hline \multirow{2}{*}{ Incubation time (min) } & \multicolumn{2}{c}{ Activity $\mu$ moles $/ \mathrm{mg}$ protein } \\
\cline { 2 - 3 } & TMP formed & $\mathrm{P}_{\mathrm{i}}$ formed \\
\hline 15 & 0.25 & 0.24 \\
30 & 0.45 & 0.44 \\
45 & 0.67 & 0.65 \\
\hline
\end{tabular}



Fig. 1. Effects of divalent cations on microsomal TDPase activity. $\mathrm{O}, \mathrm{CaCl}_{2} ; \triangle, \mathrm{MnCl}_{2}$;

-, $\mathrm{MgCl}_{2} ; \triangleleft, \mathrm{ZnCl}_{2} ; \times, \mathrm{CoCl}_{2}$. 
optimal concentration was about $4 \mathrm{~mm}$.

\section{Effects of nucleotides}

Table 3 shows the effects of ATP at low concentrations on TDPase in whole brain, brain microsomes and liver microsomes treated with acetone. The brain TDPase was not affected by ATP in the presence of either $\mathrm{Mg}^{++}$or $\mathrm{Ca}^{++}$, although the hepatic enzyme was activated by this nucleotide. Table 4 shows the effects of various nucleotides on brain microsomal TDPase. UDP, IDP and cyclic AMP inhibited the enzyme activity, and as shown in Fig. 2, IDP behaved as a competitive inhibitor.

Table 3. Effect of ATP on TDPase in an acetone powder.

Reactions were carried out in the presence of $4 \mathrm{~mm} \mathrm{MgCl}_{2}$ or $\mathrm{CaCl}_{2}$. Assay conditions are described in EXPERIMENTAL and legend for Table 2.

\begin{tabular}{|c|c|c|c|c|c|}
\hline \multirow{4}{*}{$\begin{array}{l}\text { ATP } \\
(\mathrm{mM})\end{array}$} & \multicolumn{5}{|c|}{ Activity ( $\mu$ moles TMP/mg protein $/ \mathrm{hr}$ ) } \\
\hline & \multirow{3}{*}{$\begin{array}{l}\text { Whole } \\
\text { brain } \\
\mathrm{MgCl}_{2}\end{array}$} & \multicolumn{4}{|c|}{ Microsomes } \\
\hline & & \multicolumn{2}{|c|}{ Brain } & \multicolumn{2}{|c|}{ Liver } \\
\hline & & $\mathrm{MgCl}_{2}$ & $\mathrm{CaCl}_{2}$ & $\mathrm{MgCl}_{2}$ & $\mathrm{CaCl}_{2}$ \\
\hline 0 & 0.45 & 2.64 & 4.10 & 2.98 & 11.36 \\
\hline 0.1 & 0.45 & 2.98 & 4.10 & 17.31 & 18.89 \\
\hline 0.4 & 0.45 & 2.74 & - & - & - \\
\hline
\end{tabular}

Table 4. Effects of various nucleotides on TDPase activity in acetone-treated microsomes from rat brain.

\begin{tabular}{lcc}
\hline \multirow{2}{*}{ Nucleotides } & \multicolumn{2}{c}{ TDPase activity (\% of control $\left.{ }^{\mathrm{a}}\right)$} \\
\cline { 2 - 3 }$(1 \mathrm{mM})$ & with $4 \mathrm{mM} \mathrm{MgCl}_{2}$ & with $4 \mathrm{mM} \mathrm{CaCl}_{2}$ \\
\hline ATP & 100 & 107 \\
GTP & 100 & 107 \\
ITP & - & 107 \\
UDP & 58 & 76 \\
IDP & 74 & 82 \\
ADP & 88 & 92 \\
AMP & 98 & 90 \\
IMP & 96 & 94 \\
Cyclic AMP & 79 & 82 \\
\hline
\end{tabular}

a Control (100\%) activities: with $4 \mathrm{mM} \mathrm{MgCl}_{2} 2.64 \mu$ moles $\mathrm{TMP} / \mathrm{mg}$ protein $/ \mathrm{hr}$; with $4 \mathrm{mM} \mathrm{CaCl}_{2}, 4.10 \mu$ moles $\mathrm{TMP} / \mathrm{mg}$ protein/hr. Assay conditions are the same as shown in Table 3.

\section{Effects of various drugs}

Table 5 summarizes the effects of various drugs on TDPase activity in vitro. TDPase activity was remarkably activated by phenothiazine derivatives and was inhibited by imipramine, theophylline, NADP, NADPH, N-ethylmaleimide and by 
Table 5. Effects of various drugs on microsomal TDPase activity.

\begin{tabular}{|c|c|c|c|c|}
\hline \multicolumn{3}{|c|}{ Effective } & \multicolumn{2}{|c|}{ Ineffective } \\
\hline Drug & $\begin{array}{l}\text { Concn. } \\
\text { (mM) }\end{array}$ & $\begin{array}{c}\% \text { of } \\
\text { control }^{\mathrm{a}}\end{array}$ & Drug & $\begin{array}{l}\text { Concn. } \\
\text { (mM) }\end{array}$ \\
\hline Chlorpromazine & 0.5 & 260 & Diphenylhydantoin & 1 \\
\hline Promethazine & 0.5 & 225 & Pentobarbital & 1 \\
\hline Imipramine & 0.5 & 83 & Acetylcholine (ACh) & 1 \\
\hline \multirow[t]{2}{*}{ Theophylline } & 1 & 74 & Physostigmine & 1 \\
\hline & 5 & 69 & ACh + Physostigmine & $1+1$ \\
\hline \multirow[t]{2}{*}{ NADP } & 0.1 & 81 & Noradrenaline & 0.1 \\
\hline & 0.5 & 55 & Dopamine & 0.1 \\
\hline \multirow[t]{2}{*}{ NADPH } & 0.1 & 63 & Tyramine & 1 \\
\hline & 0.5 & 49 & $\gamma$-Aminobutyric acid & 10 \\
\hline \multirow[t]{3}{*}{ N-Ethyl-maleimide } & 0.1 & 61 & Glycine & 10 \\
\hline & 1 & 53 & Taurine & 10 \\
\hline & $(\mathrm{v} / \mathrm{v} \%)$ & & Glutamic acid & 10 \\
\hline Methyl alcohol & 10 & 58 & Colchicine & 1 \\
\hline \multirow[t]{5}{*}{ Ethyl alcohol } & 5 & 70 & NAD & 1 \\
\hline & 10 & 35 & Theobromine & 1 \\
\hline & & & Caffeine & 1 \\
\hline & & & $\mathrm{KCl}$ & 100 \\
\hline & & & $\mathrm{NaCl}$ & 100 \\
\hline
\end{tabular}

a Control (100\%) activity was $0.87 \mu$ moles $\mathrm{P}_{\mathrm{i}} / \mathrm{mg}$ protein $/ \mathrm{hr}$. Assay conditions are described in EXPERIMENTAL.

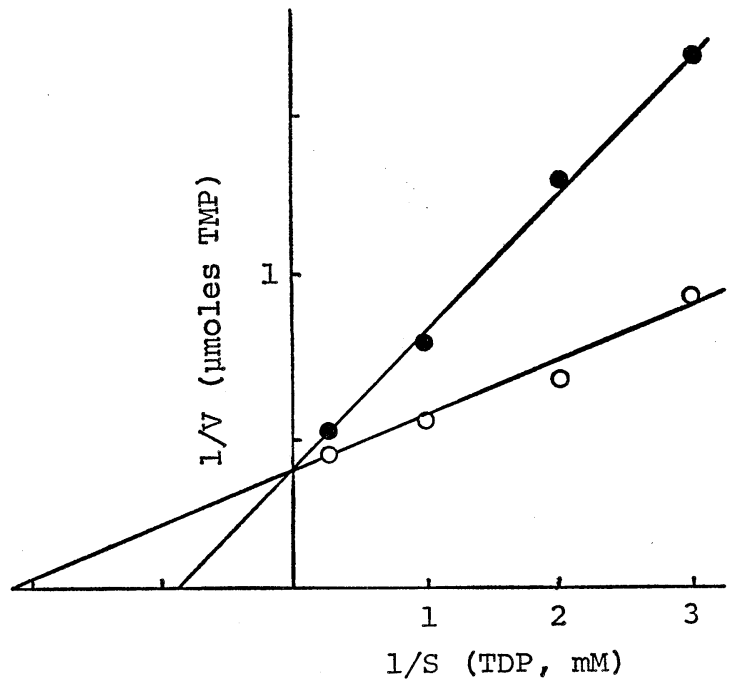

Fig. 2. Lineweaver-Burk plots of the TDPase reaction in the presence and absence of IDP. The reaction mixture $(2.7 \mathrm{ml})$ contained $75 \mathrm{~mm}$ Tris- $\mathrm{HCl}(\mathrm{pH} 9.0), 4 \mathrm{mM} \mathrm{MgCl}, 0.28 \mathrm{mg}$ of protein of acetone-treated microsomes and TDP. • with IDP; $\bigcirc$, without IDP. 
high concentrations of alcohols. Other drugs tested, including cholinergic drugs, adrenergic drugs and putative amino acid neurotransmitters, had no effect on the enzyme activity.

\section{DISCUSSION}

It has been reported that TDPase activity is probably associated with several kinds of cellular membrane $(7,8,15,16)$. We also found that the enzyme activity was mainly localized in the microsomal fraction of rat brain. Microsomal TDPase, like microsomal TTPase (4), exhibited an absolute requirement for divalent cation which was satisfied best by $\mathrm{Ca}^{++}$. In contrast BARCHI et al. (7) reported that TDPase in the myelin fraction of rat brain showed an absolute requirement for metal ion which was best satisfied by $2 \mathrm{mM} \mathrm{Mg}^{++}$but that $\mathrm{Ca}^{++}$was only slightly effective. This discrepancy may be due to differences in the subcellular fractions used.

Previously we (1) reported that TDPase in an acetone powder of rat brain was activated by low concentrations of ATP. This observation agreed with that on partial purified TDPase from rabbit brain microsomes (8). However, BARCHI et al. (7) reported that ATP had no effect on brain TDPase. Thus, the effect of ATP on the brain enzyme was uncertain. To clarify this, it is necessary to determine enzyme activity by measuring formation of TMP by TDPase, because the enzyme preparation contains ATPase activity. Therefore, we re-examined the effect of ATP by measuring release of TMP. The results showed that brain TDPase, unlike the liver enzyme, was not activated by ATP. So, we consider that our earlier result, obtained by measurement of inorganic phosphate, was erroneous.

We also examined the effects of other nucleotides by measuring TMP and found that UDP and IDP but not ADP significantly inhibited the enzyme activity. The inhibition by IDP was found to be competitive with respect to the substrate TDP, as with the liver enzyme (12). These observations support the possibility (7) that microsomal TDPase activity of rat brain is actually catalyzed by a more general nucleoside diphosphatase.

IтоKAWA et al. (17) demonstrated that neuroactive agents, such as acetylcholine, tetrodotoxin and ouabain caused release of dephosphorylated thiamine from membrane fragments of rat brain. But, it was reported that none of these agents altered the activity of brain TDPase $(7,8)$ and this was confirmed in the present work. Furthermore, recent studies demonstrated that these agents also did not affect brain TTPase $(9,10)$. These findings suggest that the release of dephosphorylated thiamine may be due to a conformational change of the membrane structure rather than to direct activation of the enzyme. Further research on the relation between the enzyme activity and the change of membrane structure is under way in this laboratory and the results will be published elsewhere.

Triphosphopyridine nucleotides, such as NADP and NADPH, at low con- 
centrations caused significant inhibition, but NAD had no effect at concentrations of 0.1 to $1.0 \mathrm{~mm}$. Triphosphopyridine nucleotide is known to act as a coenzyme of glucose-6-phosphate dehydrogenase and 6-phosphogluconate dehydrogenase, which are important in regulation of the activity of hexose monophosphate pathway. Furthermore, DreYfus et al. (18) demonstrate that thiamine diphosphate participates in the function of the central nervous system through its role as coenzyme of brain transketolase, which is also an enzyme in hexose monophosphate pathway. Thus TDPase activity may be associated with the mechanism of control of hexose monophosphate pathway in brain.

At present, we have no explanation for the inhibitory effect of theophylline on brain TDPase activity.

\section{REFERENCES}

1) Inoue, A., Shim, S., and Iwata, H., J. Neurochem., 17, 1373 (1970).

2) Iwata, H., Inoue, A., and Tomor, M., J. Neurochem., 18, 1371 (1971).

3) Inoue, A. and Iwata, H., Biochim. Biophys. Acta, 242, 459 (1971).

4) Iwata, H., Baba, A., and Matsuda, T., Japan. J. Pharmacol., 24, 817 (1974).

5) Barchi, R. L. and Braun, P. E., Biochim. Biophys. Acta, 255, 681 (1972).

6) Barchi, R. L. and Braun, P. E., J. Biol. Chem., 247, 7668 (1972).

7) Barchi, R. L. and Braun, P. E., J. Neurochem., 19, 1039 (1972).

8) Cooper, J. R. and KINI, M. M., J. Neurochem., 19, 1809 (1972).

9) Hashitani, Y. and Cooper, J. R., J. Biol. Chem., 247, 2117 (1972).

10) Iwata, H., Baba, A., Matsuda, T., Terashita, Z., and IshiI, K., Japan. J. Pharmacol., 24, 825 (1974).

11) Iwata, H., Baba, A., Matsuda, T., and Terashita, Z., J. Neurochem., 24, 1209 (1975).

12) Yamazaki, M. and Hayaishi, O., J. Biol. Chem., 243, 2934 (1968).

13) Baginski, E. S., FoA, P. P., and ZAK, B., Clin. Chim. Acta, 15, 155 (1967).

14) Lowry, O. H., Rosebrough, N. J., Farr, A. L., and Randall, R. L., J. Biol.rChem., 193, 265 (1951).

15) Novikoff, A. and Goldfischer, S., Proc. Nat. Acad. Sci., 47, 802 (1961).

16) Seijo, L. and Arnaiz, G. R. De L., Biochim. Biophys. Acta, 211, 595 (1970).

17) Itokawa, Y. and Cooper, J. R., Biochim. Biophys. Acta, 196, 274 (1970).

18) Dreyfus, P. M. and Hauser, G., Biochim. Biophys. Acta, 104, 78 (1965). 